ISSN: 2224-0616

Int. J . Agril. Res. Innov. \& Tech. 1(1\&2): 29-36, Deœmber, 2011

Available at http:// www.ijarit.webs.com

\title{
DISTRIBUTION OF NATURAL ENEMIES IN HERBIVORES OF OILSEED RAPE FIELDS IN SWEDEN
}

\author{
A.C. Halder* \\ Received 9 September 2011, Revised 22 November 2011, Accepted 25 December 2011, Published online 31 December 2011
}

\begin{abstract}
Natural enemies play an important role to control the pest population of a crop field by killing the pest directly or indirectly by parasitism. By knowing the dispersal ability of natural enemies could be effective biocontrol tool for controlling the harmful pest. Vegetated field margins have been suggested as a shelter of natural enemies. Natural enemies like ground beetle, rove beetle, parasitoid and spider dispersal ability from the field margin to inside the oilseed rape field was analyzed by doing this study. All insects were collected from the oilseed rape fields of Southern Sweden. This study showed that parasitoid abundance was higher near the field margin compare to the deep field. Distribution of ground beetle, rove beetle and spider was almost the same all over the field. Parasitoids could be effective to control the oilseed rape pest near the field margin as a biocontrol aspect whereas rove beetle, ground beetle and spider could be a used biocontrol tools for all over the field.
\end{abstract}

Keywords: Natural Enemies, Herbivores, Rape Fields, Sweden

Per Albin Hanssons väg 12, 21432, Malmö, Sweden

*Corresponding author's email: animeshhalder@hotmail.com

Reviewed by Dr. Md. Azharul Islam, Bangladesh Agricultural University, Mymensingh, Bangladesh

\section{Introduction}

Biodiversity is important for the sustainability of an ecosystem and is a functioning system of plants, animals and microorganisms (Biala et al., 2005). Currently outstanding global biodiversity loss is a result of reduced species richness and an effect of ecosystem functioning (Tscharntke et al., 2005). Many researchers have reported that intensive farming is a factor reducing species richness of birds, mammals, insects and plants at the countrywide and field level (Flynn et al., 2009). Research on the result of species loss on ecosystem functioning has increased greatly. Invertebrates are the most common and diverse terrestrial animal group on the earth and produce important ecosystem services in agriculture such as pollination, degradation of organic matter and biological control. Natural enemies perform biological control by killing the pest directly or indirectly by parasitism. For sustainable agricultural production natural enemies are an important component which helps to reduce the application of pesticide. Throughout the last decades modern farming methods have been developed dramatically which has changed the agricultural landscape. Important biotic interactions in agro-ecosystems should be affected by the changes in the agricultural landscape from structurally rich and diverse landscapes to intensively managed and cleared landscapes (Thies and Tscharntke, 1999).

There are many proposed approaches aimed at making agriculture more sustainable, as reducing the amount of agrochemicals used, and enhancing biodiversity in agricultural ecosystem. By manipulating the crops, farming practices or the surrounding vegetation, crop fields and their margins will be strengthened as natural enemy habitats. Planting flowering plants as nectar source, or planting ground covers between crop rows to moderate temperature and relative humidity could be alternative refuges for natural enemies. Perennial or annual non-crop vegetation often occurs as marginal habitats around the annual crop fields. Those non-crop vegetation field boundaries (Greaves and Marshall, 1987) give intrinsic and permanent reservoir for vertebrates and invertebrates of agricultural land, but have declined from intensive agriculture. Presence of field margin strips like grassy boundaries, wildflower strips, and uncultivated crop edges or headlands with exclusion of pesticides can improve the abundance and species richness of plants, vertebrates and invertebrates (Lagerlöf and Wallin, 1993; Boatman, 1994; Frank, 1997). Many studies have often focused on the pest or potential natural enemies of invertebrate 
populations in the field margins (Thomas et al., 1992; Hassall et al., 1992; Lagerlöf and Wallin, 1993; Corbett and Rosenheim, 1996; Barbosa, 1998). The diversity of vegetation enrichment in the weedy strips has been suggested to be higher in diversity of natural enemies than simple agroecosystems (Andow, 1983; Risch et al., 1983; Altieri and Letourneau, 1984). Natural enemies can take shelter in undisturbed habitat (field boundaries) and use resources provided by vegetation and vegetated areas may get benefit of pest control because of supporting higher abundance of predators and parasites (Olson and Andow, 2008). It has been observed that natural enemies such as parasitoids, spiders, coccinellids, staphylinids and carabids increase in abundance at the presence of vegetation (Landis and van der Werf, 1997; Pywell et al., 2005; Thomson and Hoffmann, 2009).

This study focused on the effect of field margins and the distribution of natural enemies of herbivores in the oilseed rape fields. In the oilseed rape field common major pests are: cabbage stem flea beetle (Pslliodes chrysocephala), pollen beetle (Meligethes aeneus), cabbage seed weevil (Ceutorhynchus assimilis), rape stem weevil (Ceutorhynchus napi), cabbage stem weevil (Ceutorhynchus pallidactylus), and brassica pod midge (Dasineura brassicae). Different parts of the plant are damaged at various stages of growth by these pests and reduce total yield. According to Alford (2000), parasitoids, notably braconid wasps (Braconidae), ichneumonid wasps (Ichneumonidae), and chalcid wasps (Pteromalidae), attack most of the pests of oilseed rape in northern Europe. Beside, these predators particularly ground beetles (Carabidae), rove beetles (Staphylinidae), ladybird beetles (Coccinellidae) and syrphid flies (Syrphidae) are important natural enemies for the pest of oilseed rape. In the oilseed rape field some other invertebrates play beneficial role as natural predation of pests, such as money spiders (Linyphiidae), wolf spiders (Lycosidae), soldier beetles (Cantharidae), dance flies (Hybotidae), long-legged flies (Dolichopodidae) (Alford, 2000).

Natural habitats can influence the dispersal capacities of predator species whether or not they reach crop fields (Sunderland and Samu, 2000; Tscharntke et al., 2005). Whole communities of insects can be disrupted by habitat fragmentation even if only some of the species react directly to fragmentation. Many studies have shown that the number of insect species in dissimilar associations can be affected by habitat fragmentation, specially for the afraid communities (Golden and Crist, 1999). For example, abundance and diversity of predators and parasitoids are often more strongly affected by habitat fragmentation than the abundance and diversity of the herbivorous hosts, even at the scales of a few hundred meters (Bullock, et al., 2002). In fragmented landscapes dispersal ability is important for the survival of carabid species (Kromp, 1999). Among all the predators' carabids are the dominant predators in oilseed rape fields having the greatest biomass in comparison with rove beetles and spiders (Goltermann, 1994). Spiders can be effective natural enemies of herbivore pests in crop systems as an ever-present and taxonomically diverse group of generalist predators (Riechert and Lockley, 1984; Nyffeler and Sunderland, 2003). Spiders are known to disperse aerially over long distances by ballooning on threads of silk (Greenstone et al., 1987; Weyman et al., 2002). Investigation on dispersal of natural enemies and pests distribution in oilseed rape fields from the field margin are in primary stage (Murchie et al., 1999). In general the effect of young and old, sown and unsown, narrow and wide plant field margin is little known. However, in the current study we investigated the effect of field margins on dispersal of natural enemies into the rape fields. The hypothesis of this investigation is that the abundance of all natural enemies of herbivores (insects) should be higher near the edge zones and dispersal capacity of flying insects should be higher in comparison with the non-flying predators in the oilseed rape fields.

\section{Materials and Methods}

Ten oilseed rape fields were selected for collecting the insects from the southern homogenous part of Skåne, Sweden. The insects were collected from the field margins along with transects (three) towards the center of the rape fields, at the distances; $0,20,60,100$ and 140 meters. Three fields were sampled more than 140 meter distance - one at 180 and $220 \mathrm{~m}$ distances and two at 180, 200, 260 and 300 meter distances. However, in the statistical analysis the extra length (180, 200, 220, 260 and $300 \mathrm{~m}$ ) of three fields were not included. The insect was collected by Helena Hansson of the $\mathrm{PhD}$ project "Ecosystem services and landscape structure at increased agricultural production of food, feed and biofuels."

It was placed $15 \times 20 \mathrm{~cm}$ plastic boxes were used for collecting the insects; containing propylenglycol for preserving the insect after trapping. The boxes were placed under the canopy on the ground to capture falling insects from the oilseed rape plants (Fig. 1).

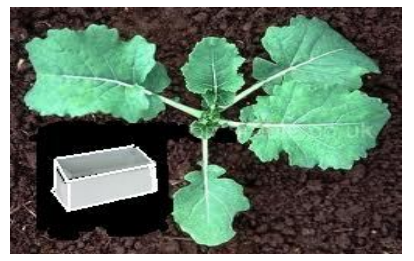

Fig. 1. Box-fall trapping system was used to collect the insects from oilseed rape fields 
The insects traps were set up from 9 - 13 of May, 2010 and collected from 26 - 28 of May, 2010. All the invertebrates were transferred to small plastic bottle with $70 \%$ of ethanol. The natural enemies were sorted and from them only ground beetle and spider species were identified to a higher taxonomic levels.

\section{Analysis of natural enemy abundance}

The number of specimen of each group collected per distance was calculated as mean of three replicates of the ten rape fields and was used in the analysis. Linear regression was used to study the dispersal capacity of natural enemies from the field margin towards inside the fields with different distances. All analyses were undertaken with SPSS for Windows (version18, SPSS Inc., Chicago, IL). All the data were entered in the Microsoft excel for primary analysis.

\section{Results}

Overall there were 3,083 specimens of natural enemies collected, analyzed as four groups: ground beetles (Carabidae), rove beetles (Staphylinidae), spiders (order Araneae) parasitoids. Among them Staphylinidae was the highest amount in number than other individuals (Table 1).

Table 1. Total number and percentage of individuals captured from the rape fields by using field traps

\begin{tabular}{lll}
\hline Captured natural enemies & Total number & Percentage (\%) \\
\hline Carabidae & 105 & 3 \\
Staphylinidae & 1529 & 50 \\
Spiders & 91 & 3 \\
Parasitoids & 1358 & 44 \\
\hline Ground total & 3,083 & - \\
\hline
\end{tabular}

A total of 105 individuals of eight species (Amara spp., Demetrias spp., Bembidion spp., Agonum spp.,Pterostichus spp., Trechus spp., Harpalus spp., Stenolophus spp.,) of carabids were collected from the field and Amara sp. was the most abundant species detected. Among these genera Amara and Harpalus (about 35\%) can eat both animal and vegetable food (Kromp, 1999). True predators genera like Agonom, Bembidion (partly) and Pterostichus (partly) have found in our investigation fields. Demetrias spp. and Trechus spp. eat aphids and Stenolophus spp. is known as seed eater carabid (Kromp, 1999). A total of 91 spiders belonging to 12 species from seven families were caught. Among them money spider was the most abundant (42) in the rape fields. Among all the insect groups Staphylinidae and parasitoids were the most abundant taxonomic groups of natural enemies though carabids and spiders were the main group of our interest.

\section{Parasitoids}

A significant difference in distribution of parasitoids was found from field margin to the inner field. Abundance of parasitoids was significantly negative correlated with the distance $(F=10.337, p=0.002)$ (fig. 2).

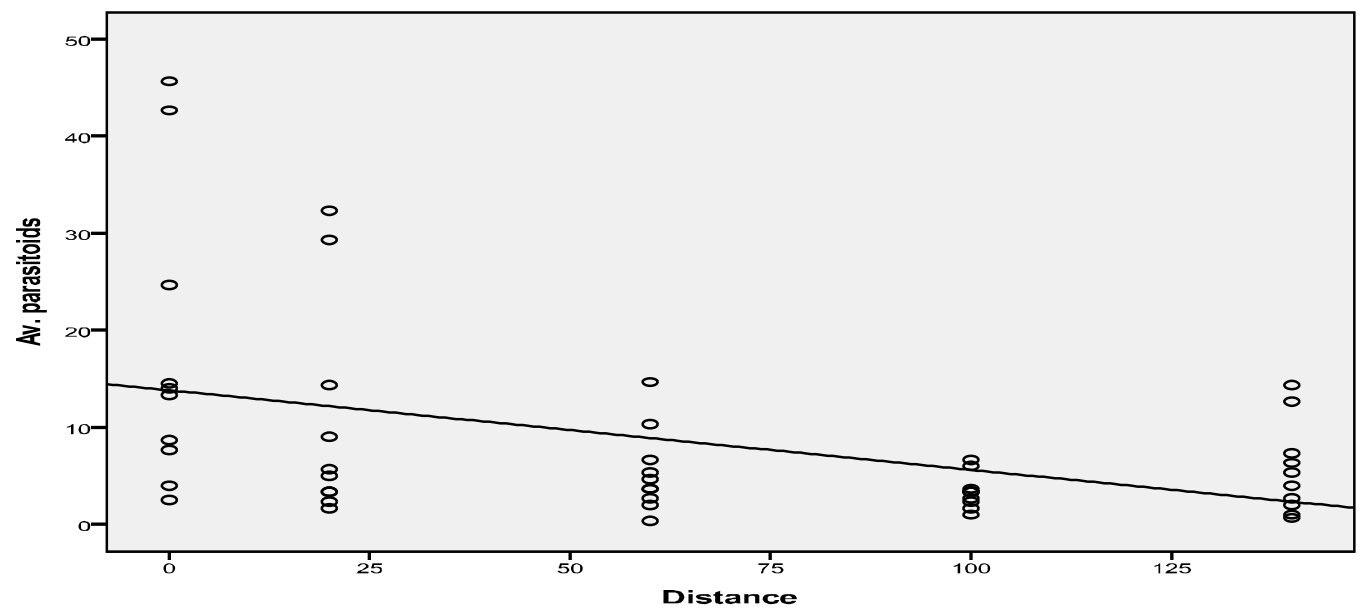

Fig. 2. Correlation of parasitoids distribution from the field margin to $140 \mathrm{~m}$ inside the field 


\section{Ground beetles}

The statistical analysis showed no differences in the distribution of carabidae between the field margins and 140 meter inside the field $(\mathrm{F}=1.352$, $\mathrm{p}=0.251$, Fig. 3).

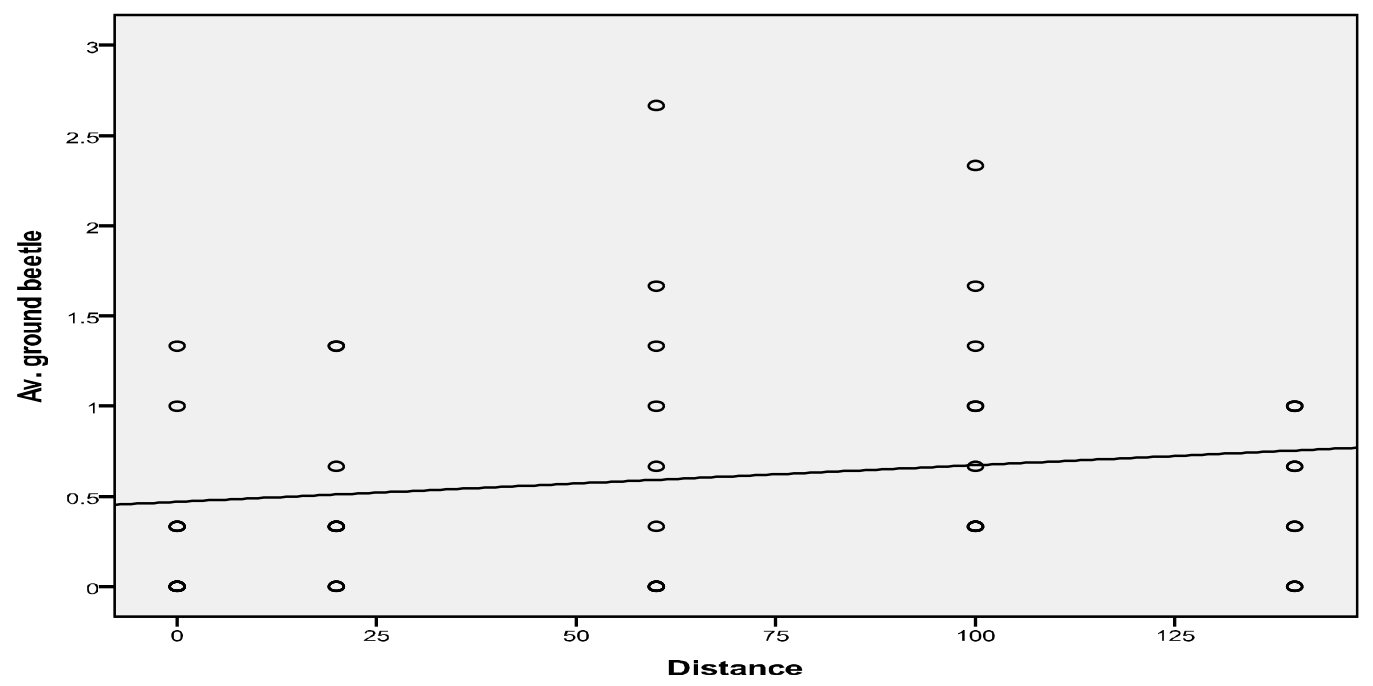

Fig. 3. Abundance of Carabidae according to the distance from the field margin to 140 meter inside the oilseed rapefield

\section{Spiders}

Regression analysis showed that spider's abundance was evenly distributed in the rape fields ( $F=.003, p=0.957$, Fig. 4). There were 12 species of spider such as money spider (common name, not specified of the species), Bathyphantes spp., Pardosa spp., Linyphia spp., Lepthyphantes spp., Heliophanus spp., Clubiona spp., Bolyphantes spp., Pityophyphantes spp., Helophora spp., Evansia spp. and Xysticus spp. Spider assemblages were dominated by typical agrobiont money spiders of the Linyphiidae family.

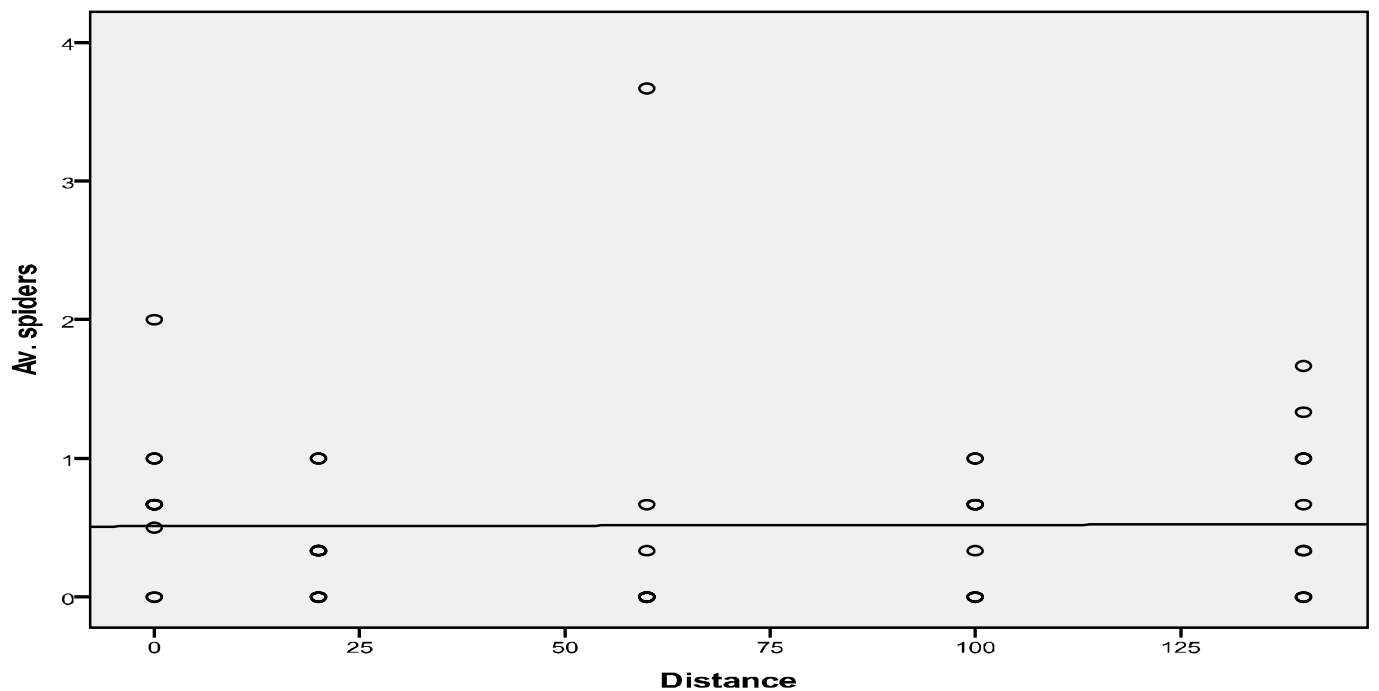

Fig. 4. Average dispersal pattern of spiders from field margin to 140 meters inside of the investigated oilseed rape field

\section{Rove beetle}

No significant difference was found in group in our study fields. They were present in every field as well as almost every trap. distribution of rove beetle from field margin to inside field ( $\mathrm{F}=1.093, \mathrm{p}=0.301$; Fig. 5). Rove beetle (Staphylinidae) was the most abundant 


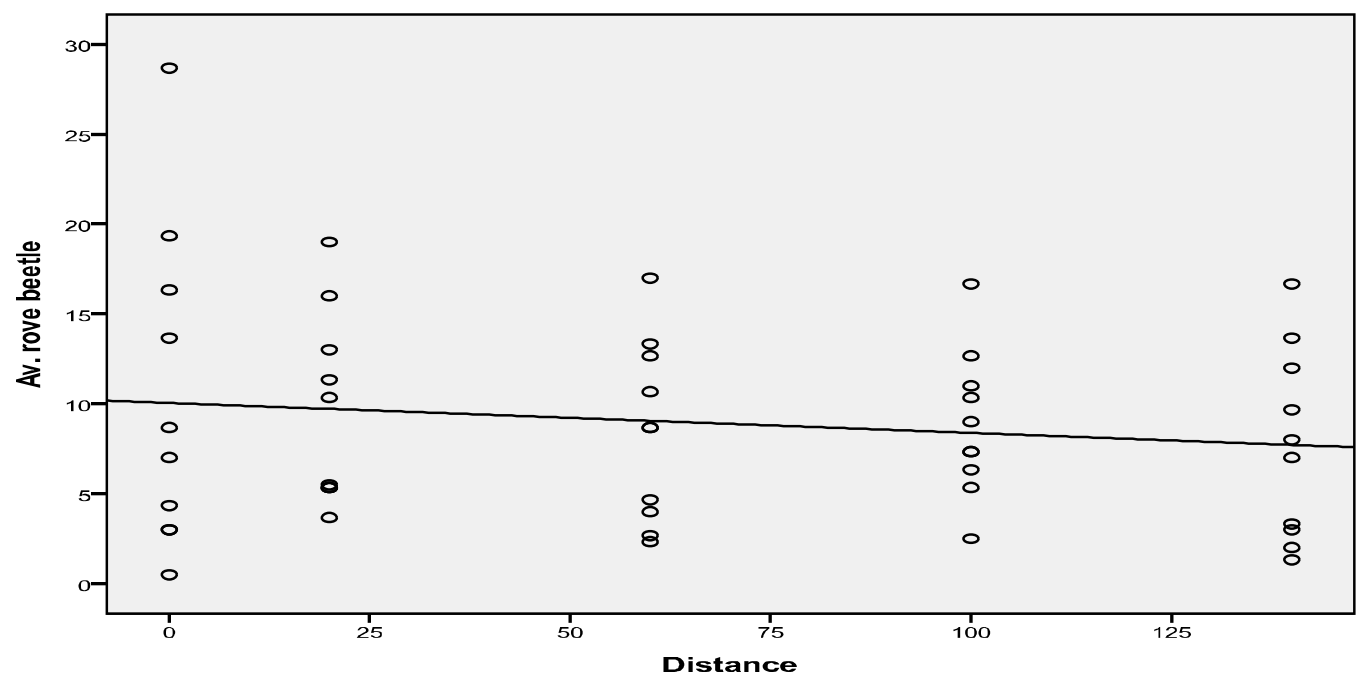

Fig. 5. Abundance of Staphylinidae in different study fields correlated with distance from the field margin

\section{Discussion}

This study revealed that the distribution of natural enemies, like rove beetle, ground beetle and spiders, in the field was not significantly influenced by the field margin. However the density of parasitoids in oilseed rape fields decreased significantly with increasing distance from the field margin supporting the hypothesis. The results of this study support the hypothesis that field margins provide habitat for beneficial insect like parasitoids, which were found more frequently and in higher numbers near field margin than inside the oilseed rape field. According to the result of a field trial of Gareau and Shennan (2010) parasitoids were more abundant near the field margin compare with inside field in Brassica crop. Availability of prey populations or resources for completing the life cycle of parasitoids may influence them to stay near the field margin. Wind also could be one factor to force small parasitoids keeping on near the field margin (Bullock, et al., 2002). It has been found that if parasitoids need to move between variable host or prey patches for the loss of local prey or host populations, they would prefer the present habitats than dispersal for future losses (Zabel and Tscharntke, 1998), although some parasitoid species have very good dispersal ability. Wright et al. (2001) observed rapid dispersal of (parasitoids) Trichogramma ostriniae over distances of 35-230 m after a release of approximate one million wasps from a central point in sweet corn field. So, at present, scientists have found that parasitoids respond less to the herbivores than to the spatial scale of the landscape, holding a common idea that a higher trophic level should be more vulnerable to disturbance (Kareiva 1990; Kruess and Tscharntke, 1994).
Rove beetles, ground beetles and spiders were found all over the oilseed rape field. This result suggests that these natural enemies may have ability to suppress pest herbivores all over the field. Most likely for creating a source sink dynamics where natural enemies may move principally from an existing habitat to another agricultural landscape (Pullium, 2000). For example, some natural enemies may attack prey populations in another habitat but could be incapable to survive their population in these habitats. In this case the persistence of natural enemies within crop fields depends on non-crop habitats around the field for a constant source of colonisers from populations (Thies and Tscharntke, 1999).

Carabidae was the main interest of investigation and Amara spp. was the most common species group in the rape fields. There was no significant dispersal difference from border line inside the field of ground beetles. That means that they have ability to predation all over the field. In Germany it has been reported higher density of carabid, 20-80 individuals $/ \mathrm{m}^{2}$ in oilseed rape field (Basedow 1973; Büchs and Nuss, 2000). But in Skåne, Sweden lower numbers of carabids (105) were captured in total from the ten fields in this investigation. Using the box-fall trapping instead of pit-fall trapping could be one explanation to get lower amount of carabid beetle in this study. In this investigation the field margin did not show any effect of carabid distribution into the field. This was opposite to our hypothesis as well as previous investigation. Fournier and Loreau (1999) found that a 2-year old and rather low (2m) hedge had higher species richness than the surrounding agricultural land and some species that were restricted to the hedge were not found in the surrounding field. Our results do not support their result. It could have been due to a different 
type of field margin. The movement capability of carabid species differs inside landscape between and within fields as well as overwintering sites and fields. Wallin and Ekbom (1988) reported that the majority carabids remain a good speed by walking or running on the soil surface in dispersal time. It has been found that in a cereal field Pterostichus niger can disperse at up to $20 \mathrm{~m} / \mathrm{h}$ (Wallin and Ekbom 1988). Faster movement of carabidae can help them to split all over the field.

Spiders are widely known as a potential pest control species, though in particular crops they show very high or low performance, dependent upon the target pest. Spider abundance was almost evenly distributed from the field margin to 140 meter inside the field. Results from the present study suggest that spiders in the rape field have the highest dispersal ability to more long distance. This dispersal capability of spiders could be an advantage for bio-control of the herbivorous pest in the rape fields. Generalist arthropod predators like spiders can play a key role in the suppression of herbivores. Money spider of the Linyphiidae family was the abundant species in our study. Thomas et al. (1991) described that linyphiids or money spiders can utilize both short and long distance dispersal strategies which is one of the best examples for bio-control aspect. Long distance dispersal occurs as a mostly passive process known as ballooning for money spiders (Duffy, 1998). Although some species are generalist predators, many species of Linyphiid spiders have a preference to live in agricultural areas, such as field or field margin, where they mainly feed on aphids (Sunderland et al., 1986). It has also been suggested that linyphiid spiders may be important for controlling outbreaks of pests in those areas where they have been disturbed by agricultural processes and are able to balloon into that areas (Sunderland et al., 1986).

The results of this study indicate that dispersal ability of rove beetles was almost same all over the field. Rove beetles showed a uniform distribution over the fields. These results suggest that rove beetles have the capacity to control prey population all over the field. An investigation result showed that about 27 species of 30 were able to fly and some species were active on soil surface (Levesque and Levesque, 1995). This result supports the wide dispersal ability of rove beetle. In addition, except litter-inhabited species most rove beetles have fully developed wing and able to fly willingly (Newton, 1990). According to Levesque and Levesque (1995), a single pair of Aleochara bilineata (Staphylinidae) adults could destroy approximately 1210 eggs and 128 larvae of Delia radicum (L.) (turnip maggot) under optimum conditions in their lifetimes. Newton, (1990) concluded that most staphylinids are nimble predators, feeding on a variety of prey including destructive arthropods. It has been reported that some rove beetle species has wide range predator characteristic in cereals including aphids, especially the bird cherry oat aphid (Kollat-Palenga and Basedow, 2002). Some species feed on fungus, pollen or various decomposing organic matters which are notable exceptions to predatory habits observed (Newton, 1984).

The prediction that all kinds of insects should be higher near the field margin was not supported except for the abundance of parasitoids. In conclusion some active predators like rove beetles, ground beetles and spiders are dispersing all over the field and could be way to control the natural enemies of the herbivores in agro-eco system.

\section{Acknowledgement}

I wish to express my deepest gratitude to my supervisors, Professor Katarina Hedlund and Helena Hansson for their skilled guidance and assistance throughout this project. I am also very grateful to Helene Bracht J ørgensen for helping me to identify the species of ground beetles and spiders and María Ingimarsdóttir for showing me the difference between flies and parasitoids.

\section{References}

Alford, D.V. 2000. Biological control of insect pests on oilseed rape in Europe. Pesticide outlook (October). An EC-funded project on the bio-control of oilseed rape insect pests. pp. 200-203.

Altieri, M.A. and Letourneau, D.K. 1984. Vegetation diversity and insect pest outbreaks. CRC Critical Reviews in Plant Sciences, 2: 131- 169.

Andow, D.A. 1983. Effect of agricultural diversity and insect pest outbreaks. Plant Sci., 2: 131169.

Barbosa, P. (ed) 1998. Conservation biological control. Academic Press, San Diego, Calif.

Basedow, T. 1973. Der Einflussepigäischer Raubarthropoden auf die Abundanz phytophager Insekten in der Agrarlandschaft. Pedobiologia, 13: 410- 411.

Biala, K., Peeters, A., Muys, B., Hermy, M., Brouckaert, V., García, V., Van der Veken, B. and Valckx J. 2005. Biodiversity indicators as a tool to assess sustainability levels of agro-ecosystems, with a special consideration of grassland areas. Options Méditerranéennes, Series A, No. 67, 439443.

Boatman, N. 1994. Field margins - integrating agriculture and conservation. British Crop Protection Council monograph no. 58. British Crop Protection Council, Farnham.

Büchs, W. and Nuss, H. 2000. First steps to assess the importance of epigaeic active 
polyphagous predators on oilseed rape insect pests with soil pupating larvae. IOBC/wprs Bull., 23(6): 151- 163.

Bullock, J.M., Kenward R.E. and Hails, R.S. 2002. Dispersal ecology. British Ecological society, published by Blackwell publishing company, Malden, USA. (ISBN: 0-632-05877-3). pp. 24-49.

Corbett, A. and Rosenheim, J .A. 1996. Impact of a natural enemy over- wintering refuge and its interaction with the surrounding landscape. Ecol. Entomol., 21: 155-164.

Duffy, E. 1998. Aerial dispersal in spiders. In: Selden, P.A. (Ed.), Proceedings of the 17th European Colloquium of Arachnology. British Arachnological Society, Burnham Beeches, UK, pp. 189- 191.

Flynn, D.F.B., Gogol-Prokurat, M., Nogeire, T., Molinary, N., Richers B.B.L., Simpson, N., Mayfield, M.M. and De-clerck, F. 2009. Loss of functional diversity under land use intensification across multiple taxa. Ecology Letters, 12: 22-33.

Fournier, E. and Loreau, M. 1999. Effects of newly planted hedges on ground-beetle diversity (Coleoptera, Carabidae) in an agricultural landscape. Ecography, 22(1): 87-97.

Frank, T. 1997. Species diversity of ground beetles (Carabidae) in sown weed strips and adjacent fields. Entomol. Res. Org. Agric., pp. 297307.

Gareau, T.P. and Shennan, C. 2010. Can Hedgerows Attract Beneficial Insects and Improve Pest Control? A Study of Hedgerows on Central Coast Farms. The center for agroecology \& sustainable food systems. University of California, Santa Cruz. Research Brief - 13, fall 2010.

Golden, D.M. and Crist, P.O. 1999. Experimental effects of habitat fragmentation on old-field canopy insects: community, guild and species responses. Oecologia, 118: 371-380.

Goltermann, S. 1994. Das Auftreten von Laufkäfern (Coleopetra, Carabidae) auf Winterrapsfeldern und deren Einfluss auf den Massenwechsel von Meligethes aeneus F. (Col. Nitulidae). PhD thesis, University of Rostock, Germany.

Greaves, M.P. and Marshall, E.J.P. 1987. Fieldmargins: definitions and statistics. Br. Crop Prot. Counc., Monogr., 35: 1- 10.

Greenstone, M.H., Morgan, C.E. and Hultsch, A.L. 1987. Ballooning spiders in Missouri, U.S.A., and New South Wales, Australia: family and mass distributions. J. Arachnol., 15: 163170.

Hassall, M., Hauthorne, A., Maudsley, M., White, P. and Cardwell, C. 1992. Effects of headland management on invertebrate communities in cereal fields. Agric. Eco. Environ., 40: 155178.
Kareiva, P. 1990. Population dynamics in spatial complex environments: theory and data. Phil. Trans. R. Soc. Lond. 330: 175- 190.

Kollat-Palenga, I. and Basedow, T. 2002. Aphid feeding of predatory Staphylinidae on different strata (soil surface and wheat seedlings) in laboratory experiments. Z . Pflanzenk. Pflanzen., 107: 643-648.

Kromp B. 1999. Carabid beetles in sustainable agriculture: A review on pest control efficiency, cultivation impacts and enhancement. Agric. Eco. Environ., 74: 187-228.

Kruess, A. and Tscharntke, T. 1994. Habitat fragmentation, species loss, and biological control. Science, 264: 1581- 1584.

Lagerlöf, J. and Wallin, H. 1993. The abundance of arthropods along two field margins with different types of vegetation composition. An experimental study. Agric. Ecosyst. Environ., 43: 141-154.

Landis, D.A. and van der Werf, D. 1997. Earlyseason predation impacts the establishment of aphids and spread of beet yellows virus in sugar beet. Entomophaga, 42: 499- 516.

Levesque J. and Levesque G.Y. 1995. Abundance, Diversity and Dispersal Power of Rove Beetles (Coleoptera: Staphylinidae) in aRaspberry Plantation and Adjacent Sites in Eastern Canada. J. Kansas Entomol. Soc., 68(3): 355-370.

Murchie, A.K., Williams, I.H., Perry, J.N. and Perry, J.N. 1999. Edge distributions of Ceutorhynchus assimilis and its parasitoid Trichomalusperfectuus in a crop of winter oilseed rape (Brassica napus). Bio-control, 44: 379- 390.

Newton, A.F.J. 1984. Mycophagy in Staphylinoidea (Coleoptera). In Q. Wheeler and M. Blackwell (eds.), Fungus/Insect Relationships, Columbia Univ. Press, New York. pp. 302-353.

Newton, A.F.J. 1990. Insecta: Cole0ptera Staphylinidae adults and larvae. In D. L. Dindal (ed.), Soil Biology Guide. J ohn Wiley and Sons, Inc., New York. Chap. 38, pp. 1137-1174.

Nyffeler, M. and Sunderland, K.D. 2003. Composition, abundance and pest control potential of spider communities in agroecosystems: a comparison of European and US studies. Agric. Ecosyst. Environ., 95: 579- 612.

Olson, D. and Andow, A. 2008. Patch edges and insect populations. Oecologia, 155: 549-558.

Pulliam, R.H. 2000. On the relationship between niche and distribution. Ecology letters, 3: 349-361.

Pywell, R.F., James, K.L., Herbert, I., Meek, E.R., Carvella, C., Bell, D. and Sparks, T.H. 2005. Determinants of overwintering habitat 
quality for beetles and spiders on arable farmland. Biological Conservation, 123: 7990.

Riechert, S.E. and Lockley, T. 1984. Spiders as biological control agents. Ann. Rev. Entomol., 29: 299- 320.

Risch, S.J., Andow, D. and Altieri, M.A. 1983. Agroecosystem diversity and pest control: data, tentative conclusions, and new research directions. Environ Entomol., 12: 625-629.

Sunderland, K. and Samu, F. 2000. Effects of agricultural diversification on the abundance, distribution, and pest control potential of spiders: a review. Entomol. Exp. Appl., 95: 1- 13.

Sunderland, K.D., Fraser, A.M. and Dixon, A.F.G. 1986. Field and laboratory studies on money spiders (linyphiidea) as predators of cereal aphids. J . Appl. Eco., 23: 433- 447.

Thies, C. and Tscharntke, T. 1999. Landscape structure and biological control in agroecosystems. Science, 285: 893- 895.

Thomas M.B., Wratten, S.D. and Sotherton, N.W. 1991. Creation of "is- land" habitats in farmland to manipulate populations of beneficial arthropods: predator densities and emigration. J . Appl. Eco., 28: 906-917.

Thomas, M.B., Wratten, S.D. and Sotherton, N.W. 1992. Creation of "is- land" habitats in farmland to manipulate populations of beneficial arthropods: predator densities and species composition. J . Appl. Eco., 29: 524531.

Thomson, L.J. and Hoffmann, A.A. 2009. Vegetation increases the abundance of natural enemies in vineyards. Biol. Control., 49: 259- 269.

Tscharntke, T., Klein, A.M., Kruess, A., SteffanDewenter, I. and Thies, C. 2005. Landscape perspectives on agricultural intensification and biodiversity- ecosystem service management. Ecol. Letter, 8: 857- 874.

Wallin H. and Ekbom, B. 1988. Movements of carabid beetles (Coleoptera: Carabidae) inhabiting cereal fields: A field tracing study. Oecologia, 77: 39-43.

Weyman, G.S., Sunderland, K.D. and Jepson, P.C. 2002. A review of the evolution and mechanisms of ballooning by spiders inhabiting arable farmland. Ethol. Ecol. Evol., 4: 307-326.

Wright, M.G., Hoffmann, M.P., Chenus, S.A. and Gardner, J. 2001. Dispersal behavior of Trichogramma ostriniae (Hymenoptera: Trichogrammatidae) in sweet corn fields: implications for augmentive releases against Ostrinia nubilalis (Lepidoptera: Crambidae). Biol. Control., 22: 29-37.

Zabel, J. and Tscharntke, T. 1998. Does fragmentation of Urtica habitats affect phytophagous and predatory insects differentially? Oecologia, 116: 419-425.

\section{Appendix}

\section{Ground beetle}

\begin{tabular}{ccccccccc}
\hline $\begin{array}{c}\text { Ground } \\
\text { beetle }\end{array}$ & $\begin{array}{c}\text { Amara } \\
\text { spp. }\end{array}$ & $\begin{array}{c}\text { Demetrias } \\
\text { spp. }\end{array}$ & $\begin{array}{c}\text { Bembidion } \\
\text { spp. }\end{array}$ & $\begin{array}{c}\text { Agonum } \\
\text { spp. }\end{array}$ & $\begin{array}{c}\text { Pterostichus } \\
\text { spp. }\end{array}$ & $\begin{array}{c}\text { Trechus } \\
\text { spp. }\end{array}$ & $\begin{array}{c}\text { Harpalus } \\
\text { spp. }\end{array}$ & $\begin{array}{c}\text { Stenoloph } \\
\text { us spp. }\end{array}$ \\
\hline 105 & 83 & 3 & 3 & 7 & 3 & 1 & 4 & 1 \\
\hline
\end{tabular}

\section{Spiders}

\begin{tabular}{|c|c|c|c|c|c|c|c|c|c|c|c|c|}
\hline Spider: & $\begin{array}{l}\text { mon } \\
\text { ey } \\
\text { spide } \\
r\end{array}$ & $\begin{array}{c}\text { Bathy } \\
\text { phant } \\
\text { es } \\
\text { spp. }\end{array}$ & $\begin{array}{l}\text { par } \\
\text { dosa } \\
\text { spp. }\end{array}$ & $\begin{array}{l}\text { Liny } \\
\text { phia } \\
\text { spp. }\end{array}$ & $\begin{array}{l}\text { Lepthyp } \\
\text { hantes } \\
\text { spp. }\end{array}$ & $\begin{array}{c}\text { Heliop } \\
\text { hanus } \\
\text { spp. }\end{array}$ & $\begin{array}{l}\text { clubi } \\
\text { ona } \\
\text { spp. }\end{array}$ & $\begin{array}{c}\text { Bolyph } \\
\text { antes } \\
\text { spp. }\end{array}$ & $\begin{array}{c}\text { pityophy } \\
\text { phantes } \\
\text { spp. }\end{array}$ & $\begin{array}{l}\text { Helop } \\
\text { hora } \\
\text { spp.. }\end{array}$ & $\begin{array}{l}\text { eva } \\
\text { nsia } \\
\text { spp. }\end{array}$ & $\begin{array}{c}\text { Xy } \\
\text { sti } \\
\text { cu } \\
\text { s } \\
\text { sp } \\
\text { p. }\end{array}$ \\
\hline 91 & 43 & 4 & 18 & 2 & 7 & 1 & 2 & 2 & 1 & 1 & 1 & 2 \\
\hline
\end{tabular}

